This is an electronic reprint of the original article. This reprint may differ from the original in pagination and typographic detail.

Author(s): Rikala, Jenni; Hiltunen, Leena; Vesisenaho, Mikko

Title: $\quad$ Teachers' attitudes, competencies, and readiness to adopt mobile learning approaches

Year: $\quad 2014$

Version:

Please cite the original version:

Rikala, J., Hiltunen, L., \& Vesisenaho, M. (2014). Teachers' attitudes, competencies, and readiness to adopt mobile learning approaches. In 2014 IEEE Frontiers in Education Conference Proceedings (pp. 2529-2536). IEEE. Conference proceedings : Frontiers in Education Conference. https://doi.org/10.1109/FIE.2014.7044408

All material supplied via JYX is protected by copyright and other intellectual property rights, and duplication or sale of all or part of any of the repository collections is not permitted, except that material may be duplicated by you for your research use or educational purposes in electronic or print form. You must obtain permission for any other use. Electronic or print copies may not be offered, whether for sale or otherwise to anyone who is not an authorised user. 


\section{Teachers' Attitudes, Competencies, and Readiness to Adopt Mobile Learning Approaches}

\author{
Jenni Rikala, Leena Hiltunen \\ Department of Mathematical Information Technology \\ University of Jyvaskyla \\ Jyvaskyla, Finland \\ jenni.p.rikala@jyu.fi, leena.r.k.hiltunen@jyu.fi
}

\author{
Mikko Vesisenaho \\ The Agora Center \\ University of Jyvaskyla \\ Jyvaskyla, Finland \\ mikko.vesisenaho@jyu.fi
}

\begin{abstract}
This study explores how teachers' attitudes and competencies influence their willingness to adopt mobile learning approaches. By mobile learning we mean teaching approaches that use mobile devices to enliven and extend traditional teaching. Of particular interest is exploring how first-order (e.g. lack of adequate access, time, training and support) and secondorder (e.g. teacher's pedagogical and technological beliefs and willingness to change) barriers affect teachers' beliefs and attitudes. In the autumn of 2012 , we conducted three mobile learning case studies in Central Finland. We used semistructured interviews to collect data. The study indicated that positive experiences raised teachers' willingness to use the mobile technologies again. Observations also highlighted the need for adequate support (i.e. technological and pedagogical support), and teachers' professional development. In particular, the teachers should have the confidence to embrace mobile technology in their teaching practices. Lack of confidence heightened other barriers and reduced the willingness to adopt mobile learning approaches.
\end{abstract}

Keywords-education; elementary school; ICT; mobile learning;

\section{INTRODUCTION}

In recent years, technologies have become an important part of everyday life. This rapid diffusion of technologies has also affected the educational context. Traditional teaching and learning approaches are insufficient to fulfill the expectations of today's learners [1]. Students come into school as digital natives, and thus the lack of technologies can frustrate them [2].

An educational technology boom was experienced particularly in the 1990s [3]. Nowadays, various technologies offer a great deal of flexibility in when, where, and how teaching is distributed. Mobile devices, for instance, can offer 'just in time, just enough, just for me' learning [4]. Unfortunately, the reality is that most classrooms look the same as they did 100 years ago, and matters are no better in those countries that have started to integrate ICT (information and communications technology or technologies) into the curriculum and pedagogy [2]. Teachers mainly prefer to use conventional technologies to reproduce old pedagogy, and textbooks still are the most common and widespread resource in schooling [5]. Some teachers do not even see mobile devices as relevant for learning [5], and many policy-makers, educators, and parents fret about disruptive behavior (e.g. text messaging during lessons, using mobile phones for cheating or bullying), and therefore think that mobile devices are an inappropriate and potentially disruptive force in education [6].

Despite the huge number of studies which have explored the barriers and difficulties around ICT integration in education, it is essential to continue to develop an understanding of the problem. In particular, information about teachers' attitudes to and beliefs about mobile learning is needed, because mobile learning pilots and trials have until now been characterized by short-term, small-scale studies which focus on learner acceptance and attitudes [7].

This paper will explore how teachers' attitudes and competencies influence their willingness to adopt mobile learning approaches. Different learning theories offer different perspectives and practices to mobile learning. The behaviorist mobile learning approach, for instance, includes 'drill and feedback' activities, while more recent approaches highlight the use of authentic contexts and real-life problems [9]. In this study, the particular interest lies in exploring how first-order (e.g. lack of adequate access, time, training, and support) and second-order (e.g. teacher's pedagogical and technological beliefs and willingness to change) barriers proposed by Ertmer [9] affect teachers' beliefs and attitudes.

The following section presents a review of the literature related to the factors that affect teachers' adoption of ICT and mobile learning. As such, it forms the theoretical framework on teachers' attitudes, competencies, and readiness to adopt mobile learning approach. The paper continues with the research method and results and concludes with reflective remarks for future research.

\section{BACKGROUND}

Teachers seem to have a growing interest in integrating ICT into education, but they can meet many barriers that can hinder the process and lessen their enthusiasm [10]. It has been repeatedly supported in the literature that integrating technology into instruction tends to move classrooms from teacher-dominated to student-centered environments [11]. Nonetheless, it is very important to realize that technologybased learning activity does not exist ready-made in a piece of 
software. The same software application can generate entirely different activities in different classrooms. Therefore, learning activities are always constituted through a situated interaction of students, teachers, and technologies. In other words, the learning culture impacts on the usage of technologies and software [12].

Five conditions can promote technology usage in an educational setting: technological infrastructure and support, teacher's beliefs and practice, curriculum, school leadership, and professional development [13]. Teachers particularly need confidence and school-level support in order to embrace technology and to change their teaching practices [14].

Three factors particularly affect teachers' adoption of ICT: the institution, resources and the teacher themselves [15]. From the perspective of the institution, the school leadership has a strong influence on resources, the curriculum, and professional development. School leaders should actively promote ICT usage through budget and funding decisions, adequate technological infrastructure and support, and opportunities for professional development [13]. A lack of ICT resources may prevent teachers from utilizing ICT in their teaching. This lack may be a result of the poor organization of resources or the concrete lack of physical devices [14]. Inasmuch as ICT integration is a very complex and multifaceted issue, teachers need professional development, and tools and techniques if they are to integrate new tools meaningfully into teaching. In other words, ICT integration can be seen as a collaboration between technologies, pedagogy, and content, and teachers need knowledge of these three components [16].

Teachers' perceptions and experiences of ICT vary and, therefore, even if teachers have up-to-date technology and support, they may not be enthusiastic enough to use technology in their classroom [15]. One very significant determinant of teachers' levels of engagement is their level of confidence in using the technology. Those teachers who consider that they are not skilled in using ICT can feel anxious using it in a classroom [14]. A teacher's confidence, in turn, is affected by the levels of adequate access, training, and support available [12]. For example, technical problems can have a direct effect on a teacher's confidence. In addition, teachers who do not realize the advantages of using technology in their teaching are less likely to use ICT [14]. The main reasons for teachers not realizing the advantages of technology are that they are not familiar with the specific tools or are not able to see the link between the tools and learning opportunities [5]. Moreover, teachers' theories of teaching are central in their ICT usage [15].

Hence, the user's overall attitude toward using technology is a major determinant of whether or not they use it. This attitude, in turn, is influenced by beliefs about perceived usefulness and perceived ease of use. In other words, people tend to use technology if they believe that it will help them to do their tasks better. However, despite any perceived usefulness, the user can believe that the technology is difficult to use and for that reason refuse it [17]. Consequently, internal beliefs can be affected by the external context and barriers.

In other words, although teachers may recognize the importance of integrating technology into curricula, their efforts may be limited by both external (first-order) and internal (second-order) barriers (see Fig. 1). The term 'firstorder barriers' refers to extrinsic obstacles such as missing resources. Second-order barriers, in turn, are rooted in teachers' underlying beliefs about teaching and learning. Even though second-order barriers may not be observable, their presence can be noticed in teachers' reasoning about their frustration. Thus, first-order barriers can be significant obstacles for technology integration, and second-order barriers can either reduce or magnify their effects [8].

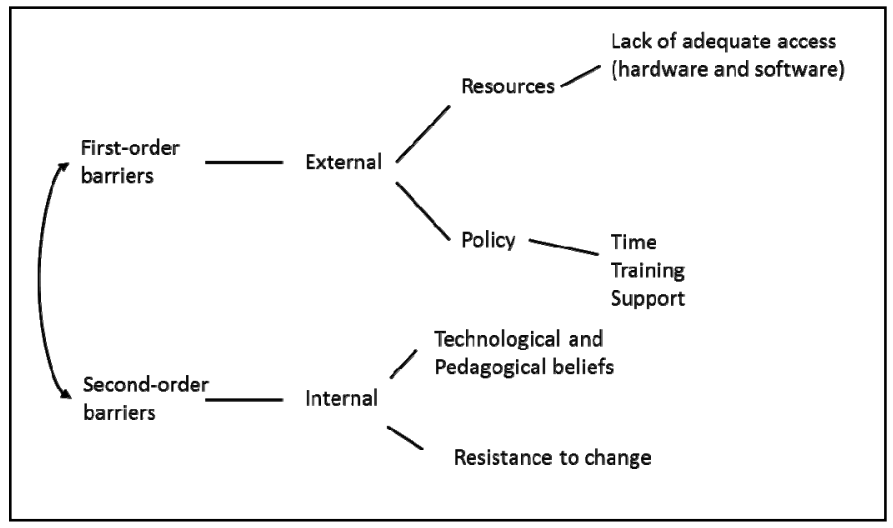

Fig. 1. First-order and second-order barriers

The majority of early integration efforts focused on eliminating the first-order barriers. The initial view was that classroom integration would happen if teachers had access to enough equipment and training. However, even if every firstorder barrier were removed, teachers would not automatically use technology. This highlights the fact that second-order barriers underlie and affect technology usage [9].

Teachers' attitudes toward mobile learning vary greatly. Many mobile learning projects in educational settings have already been initiated. However, the practice of using mobile devices is still emerging, and the concept of mobile learning has not yet reached the policy level. Projects are typically conducted on a small scale and driven by enthusiastic teachers. Nonetheless, many European governments, policy-makers, parents, and teachers treat mobile technologies as disruptive devices. Some countries have even banned or restricted mobile device usage in school. [18]

Even though teachers are central to the success and sustainability of mobile learning [19], many mobile learning pilots and trials have mainly focused on learner acceptance or attitudes. These studies have found overall student perceptions of mobile learning to be positive [20]. In addition, students' intention to adopt mobile learning has reported to be high [21; 22]. Research looking specifically at teachers' perceptions and beliefs about the use of mobile learning are somewhat limited. For this reason, it is important to understand teachers' attitudes to and beliefs about mobile learning, thus the primary interest in this study is to explore how first-order and second-order barriers proposed by Ertmer [9] affect teachers' beliefs about and attitudes to mobile learning. 


\section{DESCRIPTION OF THE STUDY}

In order to explore teachers' beliefs and attitudes, we conducted three mobile learning case studies at schools in Central Finland in the autumn of 2012. The case studies were part of the Personal Mobile Space project (see [23]).

The use of a case study method is appropriate because it can provide an in-depth examination and give an understanding of perspectives, opinions and expectations. Even though case studies have been criticized in particular for their lack of representativeness, as well as a lack of rigor in the collection, construction, and analysis of empirical materials [24], nevertheless the conclusions and explanations can be the most generalizable and most interesting aspect of case study research. The collected data may be specific to a particular school, student, or teacher, but the conclusions and explanations can be usable and generalizable in understanding how other schools, students, or teachers work [25]

For this study, three cases were selected. A total of six volunteer interested teachers cooperated when developing new ways of embedding mobile technologies for learning. We selected the cases in such way that it is possible to draw a broad picture of teachers' beliefs and attitudes from them. In other words, each case was unique, but the phenomenon under examination was the same in all of the cases; teachers' beliefs about and attitudes to mobile learning.

All of the six teachers were female. Some of them had already taught for over twenty years, and others were at the beginning of their teaching studies and teaching career: in other words, they were trainee teachers. The teachers had little or no experience of mobile learning, but were very enthusiastic to see how they could use mobile technologies in their classrooms. Cooperating with the teachers gave us the opportunity to design learning activities using meaningful content that has relevance to the school curriculum.

We used a semi-structured interview to collect data for the study. We designed the interview questions to cover the core aspects of mobile learning as well as to understand the teachers' experiences of and opinions about mobile learning. Table I presents the interview framework and themes. However, the actual questions were adapted to the individual case, taking into account, for example, the application(s) used.

TABLE I. SEMI-STRUCTURED INTERVIEW FRAMEWORK AND THEMES

\begin{tabular}{|l|l|}
\hline 1. Background information & $\begin{array}{l}\text { teaching experience, mobile learning } \\
\text { experiences }\end{array}$ \\
\hline 2. Place \& Time & what? where? when? how? \\
\hline 3. Device Aspect & ease of use, technical problems \\
\hline 4. Learner Aspect & $\begin{array}{l}\text { feasibility, learner attitudes, learner } \\
\text { motivation }\end{array}$ \\
\hline 5. Social Aspect & $\begin{array}{l}\text { possible interactions, possible } \\
\text { collaboration }\end{array}$ \\
\hline 6. Mobile Learning experiment & $\begin{array}{l}\text { opportunities, challenges, successes, } \\
\text { failures, experiences, attitudes, } \\
\text { willingness to adopt a mobile learning } \\
\text { approach }\end{array}$ \\
\hline
\end{tabular}

\section{A. The Case Studies}

The three cases, 1) Nature Tour, 2) Math Trail and 3) Literature Tree, varied in terms of mobile learning application, objectives, duration, students and teacher (see Table II). In all cases, equal opportunities were offered to take advantage of loaned equipment as well as support during the experiment. The three cases will be introduced in more detail in the following sub-sections.

TABLE II. CASE STUDIES

\begin{tabular}{|l|l|l|l|l|}
\hline Case & Objective & $\begin{array}{l}\text { Sample \& Grade } \\
\text { level }\end{array}$ & Application & Duration \\
\hline $\begin{array}{l}\text { 1 Nature } \\
\text { tour }\end{array}$ & $\begin{array}{l}\text { Early childhood } \\
\text { education: } \\
\text { nature education }\end{array}$ & $\begin{array}{l}\text { 29 students } \\
\text { (aged 6 years) }\end{array}$ & $\begin{array}{l}\text { Prototype of } \\
\text { Nature Tour } \\
\text { application }\end{array}$ & 2 months \\
\hline $\begin{array}{l}\text { 2 Math } \\
\text { trail }\end{array}$ & $\begin{array}{l}\text { Primary school: } \\
\text { mathematics }\end{array}$ & $\begin{array}{l}\text { 24 students } \\
\text { (aged 10-11 } \\
\text { years) }\end{array}$ & QR codes & 2 weeks \\
\hline $\begin{array}{l}\text { 3 Literature } \\
\text { tree }\end{array}$ & $\begin{array}{l}\text { Secondary } \\
\text { school: literary } \\
\text { history }\end{array}$ & $\begin{array}{l}\text { 16 students } \\
\text { (aged 14-15 } \\
\text { years) }\end{array}$ & QR codes & $\begin{array}{l}2 \times 45 \\
\text { minutes }\end{array}$ \\
\hline
\end{tabular}

1) Case: Nature Tour

The Nature Tour case explored the implementation of the Nature Tour mobile application in Finnish early childhood education settings. The primary objective of the Nature Tour mobile application is to enhance children's outdoor learning experiences by helping with the documentation of the field trips. A total of twenty-nine students, two teachers, and one assistant participated for two months. They used loaned smart phones that were preinstalled with the prototype of the Nature Tour application. The mobile application was used in appropriate situations on field trips to arouse children's interest in nature. The objective of the implementation was to begin nature education by observing plants and fungi in an authentic context. The researcher provided a short orientation session for the teachers, but otherwise the teachers worked independently during the two months.

\section{2) Case: Math Trail}

The Math Trail case explored the implementation of Quick Response (QR) codes in Finnish primary school. A total of twenty-four students and their teacher participated for two weeks. The overall objective of the implementation was to advance the students' mathematical skills. The learning subject and objective were to learn about decimal numbers. At the beginning of each math lesson, the teacher taught the theory and the students solved five problems from the textbook. After solving textbook problems, the students could circulate along the math trail, which included QR code activities. Each student was given one loaned smart phone and a map of the trail, including QR code locations. For each QR code location, the students answered one problem by scanning the code and submitting their answer using the online form on the mobile device. If the answer was correct, the student received a hint about the following QR code location. The math trail included a total of 65 textbook-like decimal number problems planned 
together with the teacher. The researcher prepared the online form (implemented using HTML and JavaScript) and QR codes, and provided a short orientation session for the teacher and the students on how to scan QR codes. Otherwise the teacher worked independently during the two weeks.

\section{3) Case: Literature Tree}

The Literature Tree case explored the implementation of QR codes in a Finnish secondary school. A total of sixteen students, two teacher trainees, and one teacher participated. The overall objective of the implementation was to revise lessons learned earlier about Finnish literary history. The activity included a 'literature tree,' a certain kind of map where the students were asked to place certain concepts in the right places. The QR codes contained hints, such as weblog texts and pictures, which helped the students to place the concepts in the right place on the literature tree. The graphics of the literature tree, as well as the contents of the activity, were designed by the trainee teacher, but the technical implementation, such as QR codes, was undertaken by the researcher. The researcher also provided a short orientation session for the teachers and students on how to scan QR codes, but otherwise the teachers worked independently during the QR sessions.

\section{RESULTS}

The collected data were analyzed through the first-order (i.e. external) and second-order (i.e. internal) barriers. Table III brings together the findings and observations made in the teacher interviews.

TABLE III. THE KEY FINDINGS

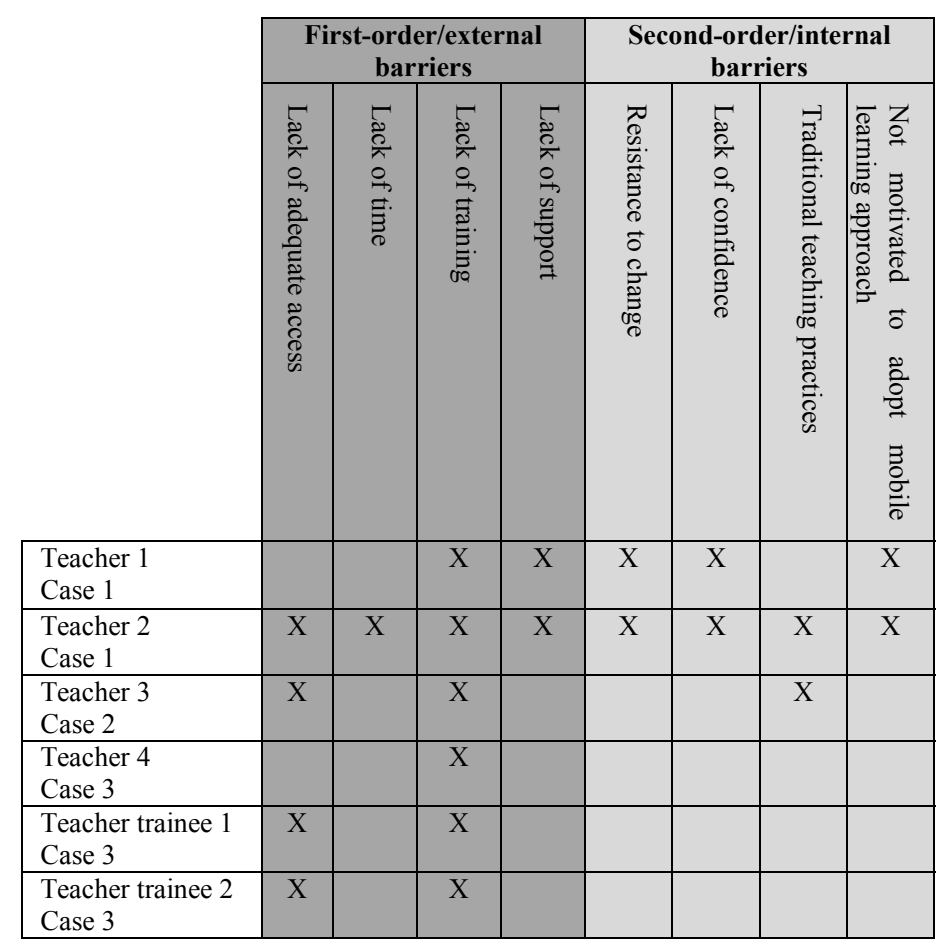

\section{A. First-order barriers and second-order barriers}

Both first-order and second-order barriers were observed in the teachers' interviews. The first-order barriers mainly concerned lack of resources and training. Mobile technologies are still a new phenomenon in Finnish education, therefore it was predictable that the teachers would think that they should have more training. In all cases, equal opportunity was offered to take advantage of loaned equipment. However, teachers highlighted the fact that a lack of adequate access could be a major barrier in the future. The second-order barriers mainly concerned resistance to change and lack of confidence. Traditional unchanged views and lack of confidence strongly affected teachers' attitudes and readiness to adopt mobile learning approaches. A positive, interested and curious attitude, in turn, gave them the courage to step out from their comfort zone. As a result, the experience was positive and gave them courage to continue. Next we will introduce the results in more detail, in the order used In Table III, including a few relevant quotes from the interviews.

\section{1) Lack of adequate access}

In all cases, equal opportunity was offered to take advantage of loaned equipment. Four teachers considered that in the future, a lack of adequate access could be a significant barrier for utilizing mobile devices as part of teaching and learning practices. In other words, one obvious challenge when implementing mobile learning is whether the school can provide the necessary tools and devices. One solution could be BYOD (Bring your own device) which means that students bring their own devices to school for educational purposes. The positive aspect of BYOD is that the students' own devices are familiar to them, and they are able to customize them to their needs. However, it is important to realize that not all students have the necessary equipment. This was also highlighted in the teacher interviews:

\section{Some students have flashy devices, but some only have standard phones, not even smart phones. (Teacher 3)}

In this sense, school leaders have a strong influence on mobile learning, as they make the decisions about the technological infrastructure and budget, and consequently the supply of equipment.

\section{2) Lack of time}

From the policy level view, opportunities for professional development as well as time for training play a major role when considering ICT usage. There are plenty of educational materials to go through as well as learning goals to be reached during the school year. Education is also scheduled on a semester, daily and hourly basis. The teacher's time for training on new techniques and approaches is quite limited. One of the participants clearly highlighted in the interview that teachers should be provided with resources and time to practice and improve their skills:

I am interested in incorporating technology into the classroom, but I complain that the employer must provide time and resources. (Teacher 2) 


\section{3) Lack of training}

All of the teachers reported that they would need more training. Because the mobile learning approach was new to them, they ended up having to repeat the same tasks that they would undertake using more conventional tools. One of the teachers, for instance, mentioned that creativity was missing, because they were not familiar with the use of mobile technology.

In particular, it seems that teachers would need training on how to solve technical problems. Three teachers reported technical problems during the experiment. In Case 1, the problems were such that solving them alone was hard. Because of this, the teachers began to think that they did not have sufficient skills, and that the mobile application was not relevant to their early childhood group. In Case 2 , the technical problems were minor and did not interfere with the experiment significantly, but frustrated both teacher and students.

\section{4) Lack of support}

All of the participants were offered equal opportunities for support during the experiment. It is not obvious why the teachers in Case 1 did not utilize this support, even though they evidently experienced some technical problems and needed help during the experiment. Solving the problems alone was hard, and the teachers began to think that they did not have sufficient skills and that the mobile application was not relevant for them.

Other teachers did not report a lack of support during the experiment. In contrast, they thanked the researcher for the support and assistance they received. For instance, a teacher in Case 2 had some problems during the experiment, but she reported that she received sufficient support and help whenever she needed, and that she felt that she did not have to deal with the problems on her own. These observations indicate the need for sufficient support.

The support should be both technical and pedagogical. Because the mobile learning approach was new for the teachers, they did not utilize the potentials of mobile technologies. However, all of the teachers realized the eminent potentials of mobile technologies. One of the teachers, for instance, commented:

When the role of the mobile application was invisible and technically automatic, you definitely would be able to apply and use it in different places and with different themes. (Teacher 2)

In all cases, the activities were more or less behaviorist, presenting learning materials, obtaining responses from learners, and providing feedback. In an ideal scenario, mobile learning activities could be arranged in authentic real-life contexts where students discover and solve problems relating to what they find. In other words, teachers would evidently need support and knowledge on how to use mobile technologies as well as how to utilize them in a more studentcentered way.

\section{5) Resistance to change}

A positive, interested and curious attitude gave the teachers the courage to step out of their comfort zone. As a result, the experience was positive and gave them even more courage to continue. The teachers in Cases 2 and 3 also noticed that students are sometimes better with the technology than them, but that this is acceptable and at times even a good thing. The teachers also reported that it is nice to use tools that are familiar to the students, and in that way come closer to the students' world. All of these observations indicate willingness to change. One of the teachers commented:

When you are considering this time and this life, then yes, you should include some good things into teaching as well. (Teacher 3)

The teachers in Case 1, in their turn, highlighted their lack of adequate skills and confidence, which were clearly reflected in their overall experience as well as their readiness and willingness to change and adopt a mobile learning approach.

\section{6) Lack of confidence}

The teachers in Case 1 were not confident, and they highlighted their lack of adequate skills during the whole interview. The lack of confidence gave rise to some fear of utilizing the mobile application. Because of this fear, the teachers opened the application for the children. They thought that they should be better able than the children in order to be able to guide them. Both teachers, however, believed that the children would have learned to use the application, but as they feared that something could go wrong, they preferred to set things up in advance. One teacher reflected on her lack of confidence:

My anxiety would have likely been a lot lower if the children had known how to use the application. (Teacher 1)

The teacher in Case 2 also highlighted that she does not have much knowledge or skills about mobile devices. She stated that the anxiety was reduced by the fact that the students already knew how to use the equipment, and that there was an opportunity to obtain support during the whole experiment.

\section{7) Traditional teaching practices}

Traditional teaching practices were particularly identified in two teacher interviews. Teachers 2 and 3 reflected on their traditional teacher-centered approaches.

Teacher 2 has over 20 years' teaching experience. The earlier short mobile learning experience was very positive, and she decided to take part again. She commented that they already had plenty of material to use, and new tools do not always integrate easily, especially if one is not technically skilled. During the experiment, she noticed that her teaching practices are quite traditional and stereotyped. These beliefs may not have been apparent to her until now, but they may have impacted on her attitudes during the experiment. She reflected:

I think that the children have also already learned our overspecialized practices. When they were asked if they are able to use the devices in the classroom, they answered no they are not. At that point, I thought that our thoughts are quite stereotyped. (Teacher 2)

Teacher 3 also has over 20 years' teaching experience. She sees mobile learning as one method of enriching teaching, but 
considers that new things should always be taught in a teachercentered way. In other words, she thinks that mobile learning could be one method of occasionally inspiring teaching, but that its constant use could be inconvenient. The experiment was interesting and she definitely would like to know about other possibilities for utilizing mobile technologies as part of teaching and learning. In other words, even though her pedagogical views are quite teacher-centered and traditional, her willingness to change and curious attitude gave her the inspiration to try something new.

\section{8) Interest in adopting mobile learning approaches}

Four teachers reported that they would try a mobile learning approach again. In particular, the positive experience gave them the courage to try again. One teacher trainee reflected after the experiment:

\section{After this experiment, I think that I have the courage to utilize mobile devices as part of my teaching practice.} (Teacher trainee 1)

When the experience was more challenging, this reduced the teacher's enthusiasm and willingness to adopt mobile learning approaches again.

\section{B. Other emerging aspects}

Two teachers (Teachers 3 and 4) highlighted the abusive use of mobile devices. This thinking about and fear of abusive and disruptive use can lead to teachers banning the mobile devices in the classroom. A further interesting research topic could be how to contribute this perception, as it could be a very significant barrier. It has been argued that teachers that begin with limited knowledge may initially provide restricted student use until they have mastered the relevant skills themselves [9]. Teacher 3 wanted to keep things under control, and highlighted that she does not have adequate skills. Perhaps this is the reason why she also commented that there should be some sort of restriction in order to ensure the safe use of devices.

The teachers' opinions about mobile learning were mainly very positive. The teachers reported that the experiment extended their thoughts and that they had started to consider additional uses of mobile technologies in an educational context. Many good suggestions were presented. However, all of them said that they would need more practice. One teacher (Teacher 3) suggested that mobile learning activities such as QR code activities, etc., could be included in and enclosed with the textbook; this would make it easier for teachers to organize mobile learning activities. She reflected:

\section{If someone made ready-made solutions, then of course I would employ them. (Teacher 3)}

One big issue that was also raised in the interviews was the fear and anxiety that teachers need to overcome before they can start to utilize mobile technologies as part of their teaching practice. The teacher in Case 3 reflected:

It is like stepping away from your comfort zone. However, when you do it, you can notice that actually you did not have to step away from your comfort zone. (Teacher 4)

\section{CONCLUSIONS}

This study explored teachers' attitudes and competencies and how they influence teachers' willingness to adopt mobile learning approaches. The primary interest lay in exploring how first-order and second-order barriers affect teachers' beliefs and attitudes.

Both first-order and second-order barriers were observed in the teachers' interviews. The barriers are more or less the same as those related to any other ICT usage. The major barriers were lack of confidence, lack of competence, and lack of access to resources. Since mitigating these barriers is also found to be a critical component for successful ICT integration [8], it is important to provide resources, professional development, and sufficient support for teachers. In other words, the findings highlighted the fact that it is important to try to eliminate first-order barriers in the case of any form of ICT integration. However, even if the first-order barriers are eliminated, the teacher still might not be willing to utilize mobile technology, for example, because of a lack of confidence. The study, therefore, also indicated that secondorder barriers exist. Second-order barriers are those fundamental internal barriers that can hinder teachers' efforts in technology implementation [9].

From a first-order barrier perspective, the school must provide the equipment needed, as not all of the students have the tools necessary for a BYOD approach. Inasmuch as mobile devices in an educational context still are quite a new phenomenon, it is also significant to provide time and professional development opportunities for teachers. One option, for instance, could be to provide easy accessible and ready-made solutions for teachers, to make it easier for them to initiate the approaches. In this way, the teachers themselves could start to develop their skills and confidence in using mobile technology as part of their teaching practice. When comfort and competence are relatively high, teachers might start to design new, creative, and student-centered ways in which to utilize mobile technology. The mobile learning activities should complement and extend traditional teaching and learning as well as offering something that it is not possible to achieve using traditional teaching and learning resources. Hence, it is important to continue to clarify the potential of mobile technologies in an educational context. How does one integrate mobile technologies into teaching and learning in a meaningful and sustainable way? One very significant observation is that the pedagogical aspect is very important. It is not worthwhile trying to reproduce old pedagogies using mobile technologies.

However, in many cases, as in the cases described in this paper, the technology is in fact often employed to reproduce old pedagogies [5]. The Nature Tour case was closest to mobile learning, as the learning was extended to the authentic context of the natural environment, and the students were able to document things as they wanted. However, the experiment had its own limitations, and not all of the core aspects of mobile learning were fulfilled sufficiently. The other two cases, involved delivering instruction through a mobile device. The same instructions could have been written on a piece of paper or spoken by the teacher. In other words, teachers need 
sufficient technical and pedagogical support as well as knowledge about technology, pedagogy, and content in order for successful ICT and mobile learning integration to take place [16]. When the technical problems are solved, and teachers have the comfort and competence to utilize technology, they will also need support to find new ways in which to integrate technology into their classrooms.

From a second-order barrier perspective, this study indicated that it seems that it is significant for teachers to have the confidence to embrace mobile technology in their teaching practices, as lack of confidence brought out other barriers more easily and reduced willingness to adopt mobile learning approaches. A positive, interested and curious attitude, in turn, gave the teachers the courage to step out from their comfort zone and to accept the fact that the students might be better with technology and that it is acceptable to ask for help if needed. It was also observed that traditional and stereotyped teaching practices influenced teachers' views and willingness to adopt mobile learning approaches. It was, for instance, observed that limited knowledge and somewhat traditional pedagogical beliefs led to restrictions on students' use of mobile learning. It was also observed that a positive experience gave teachers the courage and interest to adopt mobile learning approaches again.

This study indicated that both first-order and second-order barriers can hinder the integration of mobile technology into teaching practices. As the teacher is very central to mobile learning implementation [19], it is important to try to understand teachers' attitudes and beliefs in a more detailed way. For this reason, it is essential to continue to develop our understanding about the issue. It would be particularly important to identify specifically those factors that might affect teachers' perception that mobile devices are inappropriate, potentially disruptive, and should be banned.

Thus, to clarify the findings, more thorough evaluation studies should be conducted. Even though the teachers' views and opinions of mobile learning were mainly positive, and most of the teachers were willing to try mobile learning again, it is not possible to predict whether they are going to utilize mobile technology again or how they are going to utilize it. However, the case studies clearly extended the teachers' perceptions and initiated some ideas about how to utilize mobile technologies in the future. All of the teachers reflected on how to develop further as well as how things should be done differently and changed in the implementation. Hopefully, the case studies and positive experiments represented an incentive to utilize mobile technologies again.

It was also observed that in some cases the barriers reduced the willingness to adopt mobile learning approaches and caused negative beliefs. Is it possible to somehow change these attitudes and beliefs, or are they permanent? Did these attitudes and beliefs already exist before the experiment, or did the experiment produce them? Although many questions remain open, the findings in this study provide some insights and a good basis for continuing research into teachers' attitudes to and beliefs about mobile learning.

\section{ACKNOWLEDGMENT}

We would like to extend our sincere gratitude to all of the teachers and students for their cooperation which helped us in the completion of this study. The case studies were part of the Personal Mobile Space project funded by Tekes (the Finnish Funding Agency for Technology and Innovation) and led by Professor Pekka Neittaanmäki and Marja Kankaanranta from the University of Jyväskylä, Finland.

\section{REFERENCES}

[1] Conole, Gráinne. 2013. Designing for Learning in an Open World. New York, NY: Springer New York.

[2] Bernard, James. "Accelerating Educational Transformation Through ICT: A Global Perspective." In Tay (ed.). 2013. Creating Holistic Technology-Enhanced Learning Experiences: Tales from a Future School in Singapore. Rotterdam: Sense Publishers, pp. 209-216.

[3] Choudhary, Premanand. 2008. Distance Learning Technologies in Education. Jaipur, India: ABD Publishers.

[4] Peters, Kristine. "M-learning: Positioning Educators for a Mobile, Connected Future.” In Ally (ed.). 2009. Mobile Learning: Transforming the Delivery of Education and Training. Edmonton, AB, CAN: Athabasca University Press, pp. 113-132.

[5] Ferrari, Anusca, Romina Cachia, and Yves Punie. "Educational Change Through Technology: A Challenge for Obligatory Schooling in Europe." In $6^{\text {th }}$ European Conference of Technology Enhanced Learning, ECTEL. 20-23 September 2011. Kloos, Gillet, Crespo García, Wild, Wolpers (eds.). Towards Ubiquitous Learning: 6th European Conference of Technology Enhanced Learning, EC-TEL. London; NewYork: Springer Heidelberg Dordrecht, pp. 97-110.

[6] Dykes, Gavin and Helena R. Knight. 2012. Mobile Learning for Teachers in Europe. Exploring the Potential of Mobile Technologies to Support Teachers and Improve Practice. Unesco Working Paper Series on Mobile Learning. Paris, France: The United Nations Educational, Scientific and Cultural Organization.

[7] Rushby, Nick. May 2012. "Editoria: An Agenda for Mobile Learning." British Journal of Educational Technology, Vol. 43, pp. 355-356.

[8] Hanewald, Ria and Wan Ng. "The Digital Revolution in Education: Digital Citizenship and Multi-Literacy of Mobile Technology." In Ng (ed.). Mobile Technologies and Handheld Devices for Ubiquitous Learning: Research and Pedagogy. Hershey, PA: Information Science Reference, pp. 1-14.

[9] Ertmer, Peggy A. 1999. "Addressing First- and Second-Order Barriers to Change: Strategies for Technology Integration." Educational Technology Research and Development, Vol. 47(4), pp. 47-61.

[10] Bingimlas, Khalid A. March 2009. "Barriers to the Successful Integration of ICT in Teaching and Learning Environments: A Review of the Literature." EURASIA Journal of Mathematics, Science and Technology Education, Vol. 5(3), Special Issue: Australia, pp. 235-245.

[11] Pitler, Howard, Elizabeth R. Hubbell, Martin Kuhn, and Kim Malenoski. 2012. Using Technology with Classroom Instruction that Works, 2 nd ed. Alexandria, Va: Association for Supervision and Curriculum Development,

[12] Mercer, Neil and Karen Littleton. 2007. Dialogue and the Development of Children's Thinking: A Sociocultural Approach. New York: Routledge.

[13] Tay, Lee Y., Siew K. Lim, and Cher P. Lim. "Factors Affecting the ICT Integration and Implementation of One-to-One Computing Learning Environment in a Primary School - A Sociocultural Perspective." In Tay and Lim (eds.). 2013. Creating Holistic Technology-Enhanced Learning Experiences. Tales from a Future School in Singapore, Rotterdam: Sense Publishers, pp. 19-37.

[14] British Educational Communications and Technology Agency (BECTA), June 2004. "A Review of the Research Literature on Barriers and Uptake of ICT by Teachers", 
http://dera.ioe.ac.uk/1603/1/becta_2004_barrierstouptake_litrev.pdf. Accessed 25 March 2014

[15] Mumtaz, Shazia. 2000. "Factors Affecting Teachers' Use of Information and Communications Technology: A Review of the Literature." Journal of Information Technology for Teacher Education, Vol. 9(3), pp. 319342 .

[16] Mishra, Punya and Matthew J. Koehler. June 2006, “Technological Pedagogical Content Knowledge: A Framework for Teacher Knowledge." Teachers College Record, Vol. 108(6), pp. 1017-1054.

[17] Davis, Fred D. 1986. A Technology Acceptance Model for Empirically Testing New End-User Information Systems: Theory and Results, Doctoral dissertation. Cambridge, MA: MIT Sloan School of Management.

[18] Hýlen, Jan. 2012, Turning on Mobile Learning in Europe. Illustrative Initiatives and Policy Implications. UNESCO working paper series on mobile learning. De Fontenoy, France: The United Nations Educational, Scientific and Cultural Organization.

[19] Ng, Wan and Howard Nicholas. September 2013. "A Framework for Sustainable Mobile Learning in Schools." British Journal of Educational Technology, Vol. 5. pp. 695-715.

[20] Pollara, Pamela and Kelly Kee Broussard. "Student Perceptions of Mobile Learning: A Review of Current Research." In Society for Information Technology \& Teacher Education International Conference.
March 7 2011. Koehler, Mishra (Eds.). Proceedings of Society for Information Technology \& Teacher Education International Conference. Chesapeake, VA: AACE, pp. 1643-1650.

[21] Lu, Xu and Dennis Viehland. 2008. "Factors Influencing the Adoption of Mobile Learning.", In $19^{\text {th }}$ Australasian Conference on Information Systems. December 3-5 2008. ACIS Proceedings. Association for Information Systems, AIS Electronic Library (AISeL) Paper 56. http://aisel.aisnet.org/acis2008/56. Accessed 25 March 2014.

[22] Liu, Yong, Feng Hu, and Hongxiu Li. "Understanding Learners' Perspectives on M-learning: Results from a Survey." In EATIS '09 Conference. June 3-5 2009. Proceedings of the 2009 Euro American Conference on Telematics and Information Systems: New Opportunities to increase Digital Citizenship Conference. NY, USA: ACM New York, pp. 6:1-6:3.

[23] Kankaanranta, Marja, Pekka Neittaanmäki, and Tuula Nousiainen. eds. 2013. Arjen mobiilipalvelut -hankkeen oppimisen ja hyvinvoinnin mobiiliratkaisut. [Mobile Solutions for Learning and Wellbeing]. University of Jyväskylä.

[24] Hamel, Jaques, Stephane Dufour, and Dominic Fortin. 1993. Case Study Methods. Newbury Park, Calif.: SAGE.

[25] Gillham, Bill. 2000. Case Study Research Methods. London: Continuum International Publishing. 